\title{
THE BLITZ GOTHIC: WAR AND LANGUAGE IN ELIZABETH BOWEN'S THE DEMON LOVER
}

\author{
FLORINA NĂSTASE \\ Universitatea Alexandru Ioan Cuza University of Iaşi
}

\begin{abstract}
The paper intends to explore Elizabeth Bowen's stylistic choices in her wartime short story, The Demon Lover (1945), wherein the experience of war is rendered in gothic form as a supernatural occurrence. Bowen's predilection for framing aspects of war in an inverted manner is well-documented in such novels as The Heat of the Day (1949), and her appeal to the fantastic is part of an Irish tradition, ranging from Bram Stoker to John Banville. The paper attempts to analyze the way in which the gothic mode, particularly at the level of language, contributes to a deconstruction of the war experience and a re-examination of the psychological horror of the Other. To this end, the paper employs theoretical concepts pertaining to the sphere of the "war gothic", while also placing emphasis on modernist theories of style, specifically as they relate to Bowen's “willfully tortuous syntax" (Teekell 61) which has an almost physical, claustrophobic effect on the reader.
\end{abstract}

Keywords: war gothic, urban gothic, language and style, monster, the Other.

A suitable visual metaphor for the Gothic genre might be a ghost town which has been vacated by its inhabitants. One can see that people used to live there, but the only thing to go on is the emptiness, the mere trace of life. The Gothic operates with what is not there or what is hinted at, rather than what is. As such, the difficulties in defining the Gothic and confining it to a genre often reveal the contradictions inherent to it. The Gothic is constantly prone to self-renewal and re-definition, precisely because it is a mode in which "imagination and emotional effects exceed reason" and "ambivalence and uncertainty obscure single meaning" (Botting 3). That is to say, the Gothic avoids identification and compartmentalization; it is unwieldy and uncooperative when it comes to genre and canon. As David Punter notes in his seminal work, The Literature of Terror (1980), the Gothic lends itself more to affect than to formal characteristics, since it is rooted in terror (13). 
The Gothic may take many forms, and traces of it can be intermittently found in many works, ranging in variety "from Mary Shelley (...) to J.G. Ballard" (Punter 13), and, as such, it is because of its heterogeneity that critics tend to see the Gothic as a slippery mode, even disruptive at times. Jarlath Killeen speaks of the "polyvalence" of the Gothic, of its "monstrous" quality (168), referring to the concept of the monster as a category which cannot be pinned down in cultural discourse (168). The Gothic weaves in and out of various genres and fosters ambivalence, both on a textual and meta-textual level. Killeen also makes the argument that the Gothic is deeply modern and treacherously nostalgic, as it operates with both subversive and conservative elements (167). This is not difficult to see: one yearns to return to the ruins of the old abbey as a symbol of bygone traditions, but one is also horrified to realize what degradation and corruption lie behind such fantasies. The Gothic is always present at the confluence of nostalgia and apocalypse. Its etymology goes back to the Goths, the infamous barbarians who brought about the fall of Rome in the $5^{\text {th }}$ century, a legacy which lends the Gothic a patina of decay and rejuvenation, encapsulating both the fall of civilization and the foundation of culture (Punter, Byron 5). The Gothic mode, therefore, is ripe for explorations of sociocultural upheavals where the individual is faced with destruction and rebirth.

The urban Gothic of the Second World War perfectly epitomized such oppositions in the devastation of London during the Blitz (1940-1941), a calamity which turned the city into ruins. The Blitz reshaped the urban landscape, transforming it into a "hallucinatory, claustrophobic and labyrinthine realm" (Wasson 2). The modern Gothic of the $19^{\text {th }}$ century had already turned its attention to the industrialized, labyrinthine city and its uncanny atmosphere, but it is wartime London in the $20^{\text {th }}$ century which typifies what Chris Baldick described as a "sickening descent into disintegration", providing "a fearful sense of historical inheritance" and a "claustrophobic enclosure in space" (qtd. in Byron, Townshend xli). The modern destruction of London harkened back to horrors such as the Black Plague and the Fire of 1666 for historical inheritance, yet, the terror of the Blitz was compounded by the anonymity of the attacks and the likelihood that everything that civilization had strived for might be reduced to rubble. The Victorian effort to "tame the city" through electricity, sewage, and an underground network (Wasson 4) was suddenly rendered moot by an altered landscape which was pitch-black, dotted here and there with lugubrious search lights, a "phantasmogenetic centre" (4), capable of making Gothic tropes appear literal:

People were buried alive in their own homes, night streets turned into a bizarre dreamscape where "banshee" sirens wailed and death howled down in the form of wailing bombs, shelterers took refuge in open coffins and even familiar structures hid new and unexpected horrors, 
like the ice cream vans commandeered to carry human blood. Corpses, shop mannequins and butcher's meat lay scattered in streets, all queasy doublings of the living. (Wasson 4)

Such imagery was captured in the wartime writing of writers such as Anna Kavan, Mervyn Peake, Roy Fuller, Henry Green and Elizabeth Bowen, who countered the "dominant national mythology of British survival and emotional resilience” by showing the fractured and unstable elements in the city, the home, and in everyday relationships between people (Wasson 1). A sense of deep paranoia, fueled by the xenophobia of a "relentless propaganda machine" (2), was actively turning people against each other, widening the gap of separation caused by war. Many of these aspects are examined by Irish writer Elizabeth Bowen, whose novels and short stories published during and after the Second World War spoke of the anxieties and tensions permeating the civilian world in the wake of calamity. Bowen wrote what might be labeled as modernist "thrillers": in her seminal novel, The Heat of The Day (1948), the central spy story is actually a deconstruction of wartime language, secret histories and secret selves (Lassner 125). Bowen often deconstructs genre and plays with readers' assumptions to an almost unsettling degree. In the short story "The Demon Lover," published in the volume The Demon Lover and Other Stories (1945), Bowen weaves Gothic imagery with an idiosyncratic language style in order to tell a supernatural story about war, where the war is the supernatural element.

In the story, Kathleen Drover, a well-to-do Londoner, has retired to the countryside due to the ravages of the Blitz, but she occasionally makes trips to her empty house in the city to run errands. The scene is set on the day of her arrival with a description of the empty street that gives an inkling of Bowen's stylistic strategies in rendering the "ghost town":

It was late August; it had been a steamy, showery day: At the moment the trees down the pavement glittered in an escape of humid yellow afternoon sun. Against the next batch of clouds, already piling up inkdark, broken chimneys and parapets stood out. In her once familiar street, as in any unused channel, an unfamiliar queerness had silted up; a cat wove itself in and out of railings, but no human eye watched Mrs. Drover's return. (Bowen 1)

From the very first sentence, Bowen sets a trap with several connecting strings. We may notice the rather unusual punctuation in her description of the day: a semi-colon after "August" and a colon after "day". The author places stilted pauses between statements that would do better with a full stop. Yet, it is precisely the tension between a pause and a full stop that Bowen seeks to cultivate as she introduces the scene. In fact, the entire story dwells in such eerie pauses that, at first, seem only to indicate emptiness. Indeed, the description 
goes on to tell us that the wrecked city landscape has little to offer except desolation. However, there is a foreign agent within that desolation, an "unfamiliar queerness" (Bowen 1) which has deposited like silt in an "unused channel” (1), foreshadowing a possible blockage. Indeed, this harkens back to what Chris Baldick described as a "claustrophobic enclosure in space" (qtd. in Byron, Townshend xli). The city is empty, yet it is precisely that emptiness which is teeming with ominous significance. To further the point, we are made aware of the presence of a cat, weaving in and out of the railings, its body a fractured image that is meant to reflect Mrs. Drover's own fractured view. At the same time, the presence of the cat is another trap. When the narrator tells us that "no human eye watched Mrs. Drover's return" (Bowen 1) we might be tempted to think that the non-human referent is the cat in question, but the "eye" belongs to someone else, a non-human entity of ambiguous origins that Mrs. Drover will only confront at the end of the story.

Upon entering the house, Mrs. Drover is welcomed by "dead air" (Bowen 1), which "[comes] out to meet her" (1), a personification that, at first glance, may seem like a stylistic detail, but which, in hindsight, foreshadows the "dead" non-human element that eventually tracks down Mrs. Drover. She is also forced to give the door "a push with her knee" (Bowen 1), since it had been warped by disuse, hinting at future violence and contortion. The woman finds a mysterious letter on one of the tables inside. Under normal circumstances, the object would not raise much suspicion, but since this is wartime London, its appearance poses a problem which the protagonist attempts to solve:

Who, in London, knew she meant to call at the house today? (...)
Letters dropped in at doors of deserted houses do not fly or walk to
tables in halls. They do not sit on the dust of empty tables with the air
of certainty that they will be found. There is needed some human hand
- but nobody but the caretaker had a key. Under the circumstances she
did not care to consider, a house can be entered without a key. It was
possible that she was not alone now. (Bowen 3)

We are able to follow Mrs. Drover's trail of thought - from contemplating her schedule to contemplating the idea of an intruder - like descending steps in a spiral. In fact, the syntax that the author employs resembles a descending spiral that manifests itself in the text through the use of participles and the passive voice: "letters dropped in at doors", "there is needed some human hand", "a house can be entered" (Bowen 3). The paragraph does not only shed light on Mrs. Drover's troubled state of mind, but also induces a similar experience in the reader. Both the participles and the passive voice render the reading stark and disembodied, announcing once again the presence of something non-human and dead. "There is needed a human hand" is a rather clunky way of expressing that only a person could have put the letter on the table inside the locked house, 
but the phrasing is consciously unwieldy as to make us pause and consider the absence of a human hand and the presence of something entirely different. Indeed, Bowen confirms that she prefers to make her readers uncomfortable, to "keep the jars, 'jingles' and awkwardness" in order to make the reading experience "eventful" (qtd. in Teekell 62). In this way, Bowen draws attention to both a presence and a lack of presence.

Certainly, the house itself gives us clues of a malevolent agency that is connected to its abandoned state. We learn that "the piano, having gone away to be stored, had left what looked like claw marks on its part of the parquet" (Bowen 1) and Mrs. Drover takes note of many bruises and cracks in the rooms around her, but it is only when we read the letter that we understand the connection between this ominous presence and the decay around it.

The letter, we learn, is from Mrs. Drover's previous fiancé, a soldier who briefly courted her during the First World War and who subsequently died on the front. The eeriness of the letter is twofold; on the one hand, the letter is written and dated in the present, suggesting that the soldier is still alive and waiting for her, but on the other hand, it seems that the man has been watching her for a long time, as he mentions that, "I was sorry to see you leave London, but was satisfied that you would be back in time" (Bowen 2). The soldier is confident that Kathleen has not forgotten their "anniversary" and that she is able to honor it, "in view of the fact that nothing has changed" (2). Yet we know that a lot has "changed" for Mrs. Drover, who is now married with children. Perhaps, then, what the soldier is referring to is a larger, unchanged state: the war itself. The young man who left for the war has returned to find the same war, only in greater, more horrifying proportion. As Eleanor Salotto posits, "history is that which follows us like a ghost; it is a return upon a present that must be dug up" (137). Inevitably, the soldier's return is not simply a supernatural event, but rather a Gothic "return" of the dead who have been buried by "history."

The reckoning of the dead is foreshadowed in the soldier's words to young Kathleen. In a flashback of their last meeting before his departure in 1916, the young man promises her that, "I shall be with you (...) sooner or later. You won't forget that. You need do nothing but wait" (Bowen 3). Such statements, in hindsight, address not only Kathleen but the entire country. Indeed, sooner or later, the ghosts of war return. Even before he has taken his leave, the soldier has become anonymous, deprived of any personal, humanizing features. Kathleen remarks that she "had not ever completely seen his face" (Bowen 2) and that "it felt, from not seeing him at this intense moment, as though she had never seen him at all” (2). Such anonymity is reinforced by Bowen's syntax which makes use of the passive voice, once more, for a dehumanizing effect: "Being not kissed, being drawn away from and looked at intimidated Kathleen till she imagined spectral glitters in the place of his eyes" (Bowen 2). In this instance, the author plays with the possibility of the 
supernatural, while also hinting at the fact that the cruelties of war are unnatural in their own right and make people unnatural. The soldier is an uncanny figure precisely because he is a soldier.

Coming back to the present moment, Mrs. Drover is quite alarmed at the prospect of their meeting and frantically contemplates an escape: "the thing was to get out. To fly? No not that" (Bowen 4). Yet there is an underlying sense in the text that such an occurrence cannot be avoided, that the casualties of the previous war cannot be buried under the rubble of the second. Indeed, as the woman exits the house, there are "eyes" watching her in the empty streets: "The unoccupied houses opposite continued to meet her look with their damaged stare (Bowen 4). Even the ruins express the inevitability of confrontation. What Bowen achieves through these personifications is a sense that the ghostly presence is the war itself and its ruinous aftermath, which finds expression in empty streets and abandoned houses, watchful windows, eerie letters, curious cats and angry pianos. The author, thus, gives a palpable account of what Wasson described as a "hallucinatory, claustrophobic and labyrinthine realm" (2).

In the last portion of the story, Mrs. Drover is hectically trying to find a taxi "before any clock struck what could be the hour" (Bowen 4), because she is still hoping to return to the countryside by train. Rather than a clock ticking in the distance, there is the absence of the clock, the uncertainty of the hour. In fact, the striking of the clock comes once she has made her choice and approached a waiting car:

At the square's most populous corner should be-and was-the short taxi rank. This evening, only one taxi-but this, although it presented its blank rump, appeared already to alertly be waiting for her. Indeed, without looking round the driver started his engine as she panted up from behind and put her hand on the door. As she did so, the clock struck seven. (Bowen 5)

The dashes that interrupt Mrs. Drover's train of thought force pauses on the reader with the effect of amplifying the tension. In particular, the dash after "only one taxi - but this" (5) seems to mirror Mrs. Drover’s quick breathing: "as she panted up from behind." The description of the taxi's "blank rump" also unsettles the reader as it seems to attach flesh and blood to the vehicle, suggesting a thing in between, non-human, yet still alive. In this way, Mrs. Drover seems to be approaching an animal lying in wait. The suspense is finally released in the final moment when our protagonist realizes she has not managed to escape the spectral meeting, after all:

The driver braked to what was almost a stop, turned round, and slid the glass panel back: The jolt of this flung Mrs. Drover forward till her face 
was almost into the glass. Through the aperture driver and passenger, not six inches between them, remained for an eternity eye to eye. Mrs. Drover's mouth hung open for some seconds before she could issue her first scream. After that she continued to scream freely and to beat with her gloved hands on the glass all round as the taxi, accelerating without mercy, made off with her into the hinterland of deserted streets. (Bowen 5)

For the greater part of the story, the eyes watching Mrs. Drover have been invisible and disembodied; only now is the woman able to see her captor: "for an eternity eye to eye” (5). The meeting of eyes is arguably the biggest shock to Mrs. Drover because she is finally able to put a face to the man whose appearance she could not remember. Now, he can no longer be ignored or cast into distant memory: his features have become visible and he has achieved a grotesque humanity, the irony being that Kathleen is only able to see this humanity in death.

The monster, as described by Jarlath Killeen, is endowed with polyvalence and is therefore difficult to categorize (168), which is what makes him monstrous. In the same vein, the soldier, whether a ghost or a corpse (or anything in between) disrupts social categories and enhances the nightmarish vision of the city. He is not an aberration of war, but rather its symptom. No one hears Mrs. Drover's screams as she is drawn further into the emptiness of the "deserted streets" (Bowen 5) and we may deduce a very bad outcome for her, not because her captor is a monster, but rather because the war has made everything monstrous. The woman, thus, becomes a part of the monstrosity as she enters the "hinterland," which can be defined as a remote and unknown place, a place beyond human boundary. A final remark may draw attention to the fact that even her married name, "Drover" is a merging of the words "drove" and "her," solidifying her inescapable fate and the idea that her life as a married woman has been as ghostly as the soldier's existence.

In the preface to the collection, The Demon Lover and Other Stories, Elizabeth Bowen described the content of her wartime stories as "a rising tide of hallucination” (qtd. in Bennett, Royle 168), and it is precisely this "rising tide," coupled with the author's "willfully tortuous syntax" (Teekell 61), that makes her writing a vivid experience of war, as she quite literally wars with the words on the page. Making use of Gothic war imagery and supernatural elements, Bowen draws attention to the uncanny, unnatural essence of war and the dehumanizing effect it works on its victims, while also showcasing its eerie potential through the use of language. 


\section{References:}

Bennet, Andrew, Nicholas Royle. Elizabeth Bowen and the Dissolution of the Novel. New York: Palgrave Macmillan, 1995. Print.

Botting, Fred. Gothic. London: Routledge, 1996. Print.

Bowen, Elizabeth. “The Demon Lover”. The Demon Lover and Other Stories, 2014 http://omero.humnet.unipi.it/matdid/201/DemonLover.pdf.

Byron, Glennis, Dale Townshend. The Gothic World. Abingdon: Routledge, 2014. Print.

Killeen, Jarlath. History of the Gothic: Gothic Literature 1825-1914. Cardiff: University of Wales Press, 2009. Print.

Lassner, Phyllis. Elizabeth Bowen. London: Macmillan, 1990. Print.

Punter, David. Glennis Byron. The Gothic. Oxford: Blackwell Publishing, 2004. Print.

Punter, David. The Literature of Terror: Volume 1: The Gothic Tradition. New York: Routledge, 2014. Print.

Salotto, Eleanor. Gothic Returns in Collins, Dickens, Zola, and Hitchcock. New York: Palgrave Macmillan, 2006. Print.

Teekell, Anna. "Elizabeth Bowen and Language at War.” New Hibernia Review / Iris Éireannach Nua, vol. 15, no. 3, 2011, pp. 61-79., www.jstor.org/stable/23068127

Wasson, Sara. Urban Gothic of the Second World War. Dark London. New York: Palgrave Macmillan, 2010. Print.

\section{BIONOTE}

Florina Năstase is an Assistant Lecturer at “Alexandru Ioan Cuza” University of Iaşi. She holds a PhD in American poetry and teaches practical courses and seminars on British neoclassicism and British modernism. She writes poetry in her spare time and has published a few poems in various magazines online.

E-mail: fnastase60@yahoo.com 